\title{
アンデス南部の地質・古生物学的研究
}

\author{
前田四 郎* 干 坂 武 志**

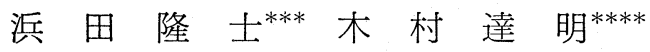 \\ 田 附 治 夫*****
}

\section{Geological and Palaeontological Researches to the Andes}

By

\author{
Shiro MaEda, Takeshi Chisaka, Takashi Hamada,
}

Tatsuaki KIMURA and Haruo TAZUKE

Under close international cooperation the research was carried out from early September in 1970 to early Junuary in 1971 to the Andes situating between Chile and Argentina.

The purposes of our research are as follows:

A) To collect fossil molluscas and plants in the field work in various localities from the stratigraphical point of view. B) To make clear what is common and what is different between the fossils in Japan and those in the Andes through the comparative study with both of them. C) To make clear the geographical distribution of fossils in Pacific region including Japan and the Andes. D) To make clear the relation between the crustal movement and the change of fossils in the geological age.

The Andes is so wide that we divided the area for our research into five districts: Copiapo-Antofagasta, Santiago, Concepción and its southern part (Madre de Dios), Mendoza, Patagonia and Sierra Australes, where we had the bases for the field work. The headquarters for whole research was located at Santiago, the capital of Chile. The materials collected by us in these districts were gathered at the headquarters in Santiago, and they were sent to Japan from Valparaíso harbour in Chile.

Although the materials are being examined now, the results of the study already known are as follows :

1) In the Cerritos Bayos near Calama, Northern Chile, the Jurassic system which was reported by BIESE in 1956, 1957 and 1961, ranging from Sinemurian to Tithonian, was clarified stratigraphically, but we could not confirm in detail BIESE's fossil zones.

2) Limon Verde area located about $20 \mathrm{~km}$ south from Calama forming high plateau, are occupied by the Palaeozoic or pre-cambrian and Mesozoic groups and igneous rocks. The Jurassic system mainly consisting of the alternation of medium to coarse-grained

* 千葉大学留学生部

** 千葉大学教育学部

*** 東京大学教養学部

***** 目白学園女子短期大学

***** 千葉教育センター 
sandstone, black shale and grey limestone, yields such molluscan fossils as Frenguelliella sp., Weyla alata (van BucH), Mactromya n. sp., Chlamys cf. textoria (Schlotheim). Judging from the molluscan fossils, the alternation is probably lower Jurassic in age.

3) Domeyko range is situated at the west of the Andes. The west slope of the range crops out the alternation of sandstone and shale. It was extremely folded by the crustal movement. The alternation contains such fossils as Cardinia sp., Protocardia n. sp., Astarte sp. and Thracia sp.. From these fossils it is thought that the alternation is lower Jurassic.

The eastern slope of Domeyko range near Sal de Punta Negra consisting of the alternation of sandstone, shale and limestone, occurs the molluscas such as Eopecten sp., Pinna sp., Minetrigoniinae gen. and sp. nov. etc.

4) In Concepcion area there were found many kinds of deposits such as Palaeozoic or pre-cambrian, Mesozoic and Cenozoic groups. There is also a broad distribution of the Palaeozoic granitic rocks forming coastal range.

The Triassic formation along the Bio Bio river consisting of clayslate, greywacke, arkose sandstone and conglomerate is marine and non-marine deposits. From the northern area of the river many plants were collected. And some specimens of Halobia were found at the point of about $2 \mathrm{~km}$ south of Unihue.

The upper Cretaceous Quiriquina formation which is distributed in the Quiriquina island, is well exposed in the western and eastern sides of the island. Many molluscan fossils including Pacitrigonia were collected in the western side of the island. On the contrary, in the eastern side, many Cretaceous plants including Dicotyledoneae were newly founded in the upper part of the Quiriquina formation close with "Eocene" marine deposit.

5) The basal conglomerate of the Quiriquina formation typically developes at the south-western side of the island. It lies unconformably on the Palaeozoic or pre-cambrian group. Because the pebbles are distinctly different in the kind of rocks and roundness from those of the basal conglomerate in the "Eocene" formation in this island, it suggests the fact that a great change has occurred in the provenance of the sediments in the interval between the upper Cretaceous and "Eocene".

6) Several fusulinids were obtained from Madre de Dios, southern part of Chile. There were found a great many numbers of each species, but the kinds of species were quite few. Among them, Triticites sp. B is alike Triticites ellipsoidalis type which indicates lower Permian (TAKAOKA, 1959). Judging from some facts that Triticites of upper Carboniferous, species of Neoschwagerina and Yabeina zone were not found from the collections, the localities of fusulinids of the islands may be lower Permian.

7) Favosites and fish remains were discovered from the several localities in the Devonian deposit along the San Juan river in Argentina. Especially the discovery of the latter is first one in this country.

8) Most interesting Cryptonellas were collected near the pass, east of Tornquist. Permian Glossopteris and other plants were obtained from quarry of Las Mosazas in Sierra Australes. 


\section{I. 緒 言}

本研究の現地調查は昭和 45 年 9 月初旬から昭和 46 年 1 月初旬にわたつて行なわれた。アンデス地域と 日本列島との地質・古生物学上の比較検討は, 環太平洋の諸地域の地質・古生物学上の特色を明確にし, ひいては太平洋の生成発展の究明のために，きわめて重要であると考えられるにもかかわらず，わが国に おいてはこれまであまり研究がすすめられてはいなかつた。われわれはこの重要性に着目し，今回現地調 查を行つたものである。研究すべきことがらは多いのであるが，その目的は，南米アンデスの古動物・古 植物を層位学的立場を考慮して収集し，わが国の古生物群とそれらとを太平洋の一環として比較検討をす す內，わが国と南米アンデス地域の古生物の共通性と特異性とを明らかにするとともに，環太平洋の古生 物の地史的分布とそのうつりかわり, および進化の要因, 特にアンデス地域における地殼変動と生物の変 遷との関倸を究明することにある。

現地調査ははじめての調查であるにもかかわらず，予期以上，きわ放て順調であった。したがって研究 目的の第一歩である資料収集も予期以上の多量を得ることができたのは幸いであつた。また，われわれは 現地調查をとおし，チリ・アルゼンチン両国との文化の交流，親善関係を深めることにも努力し，その成 果もあげることができた。

収集した資料は目下室内研究中であるが，本文では野外調查で知り得た諸事実や室内研究によつて判明 した内容についての概要を記す。

\section{II. 現地の協力関係}

わが国の研究者による従来の南米アンデス地域の古生物学的研究は，二三を除けば，きわめてとぼしい 状態で，古くからしんぼう強く調査研究を行なつてきた欧米人のそれらに比へ，量的にはまことにみお之 りのするものであつた。アンデス地域における古生物学上の研究歴史の浅いわが国から出発して, 現地で 調查を実施するにあたつては，実際に，現地の研究機関の協力なしには不可能といつて過言ではない。言 語, 習慣上の差違, 調查のための移動など, 種々の支障が充分に予想されたので, 出発前から現地の日本 大使館を中心に，相手国の公的機関とつね緊密な連絡をとつた。その結果，現地では関係機関から絶大 な協力が得られ，野外調査はきわめて円滑に実施できた。主な協力機関壮次のとおりである。

\section{1. チリ}

在チリ国日本大使館 (Embajada del Japón, Santiago), チリ国地質調查所 (Instituto de Investigaciones Geologicas, Santiago), 同コピアポ分室 (Oficina Regional de Antofagasta), 同コンセプシオン 分室 (Oficina Regional de Concepcion), チリ大学 (Universidad de Chile, Santiago), 日本貿易振興 会(Jetro, Santiago)。

\section{2. アルゼンチン}

在アルゼンチン日本大使館 (Embajada del Japón, Buenos Aires), アルゼンチン国経済局地質調查所 (Ministerio de Economia y Trabajo, Direccion Nacional de Geologia y Mineria, Buenos Aires), ブ エノスアイレス大学 (Universidad de Buenos Aires)，ラプラタ博物館 (Museo de La Plata)。

上記の公的機関のらち, とくにチり国地質調查所の協力支援が本研究を成功させた最大要因であったと 考えられる。すなわち鉱床学の Carlos RUIZ F. 所長を中心に, 古生物学の José CORVALÁN D. 副所長 (地方地質部長), 涉外の Carlos FONTAINE G. 部長らが実情にあつた緻密な野外調査のプランを作成 し，そのプランどおりに強力に推進された。すなわち，われわれの野外調查の移動に伴つて地質調查所の 各地方区の分室が，その責任区域について徹底した協力を示された。われわれの構成員がどこの地区に移 動してもチり国側協力者に趣旨が徹底理解されており，そのために無䭾のない調查研究が実施された。ラ テン系民族の習慣として一般によくいわれるような時間上の不規則性は，われわれと接触した調査機関の 
メンバーにかぎつては全くみられなかつた。日本からのはじめての古生物学調査隊といらことで，受け入 れ側も極度に緊張の連続であつたとおもわれる。収集資料の出国の手続き, 野外調査上の車の手配, 北部 チリでの野営地の設定, ことにチリ南端フィヨルド地帯の古生層の研究地への Santiago からの諸物資の 空輸, また海軍基地である Quiriquina 島の上部白亜系および第三系の基底䃋岩の比較研究には, 研究の ための入島許可のみならず古生物学資料の収集とその運搬にチリ国海軍の強い支援を得るに至つた交渉々 手続きなど，チリ国地質調查所の協力は非常によくなされた。

\section{III. 調査経過の概要}

調查対象地域はチリとアルゼンチンの両国にまたがるアンデスであるので，日本からの通信連絡および 調査用器具機材などの発送先はもつとも便利なチリの首都 Santiago とし, ここ在調査上の根拠地とし た。本部には日本人会館 (Sociedad Japonesas: Andres Bello, 1429, Santiago) があてられた。日本人 会館からチリ国地質調查所へはバスで容易にかようことができ，いつぽう，チリ国地質調查所は日本大使 館とごく接近していたので好都合であつた。日本人会館は Santiago の中心街から南にあつて閑静な環境 にあり，在住邦人との連絡もよくとれるので調查上のプランニングには最適の場所である。したがつて， これまでにもアンデスをおとずれる各方面の学術調査隊はこの日本人会館を本部とされていることが多 い。

アンデス山脈は南北に長くのびているので, 調查の実施にあたつては, 研究地を五つの主要地域に区分 し，そのおのおのに野外調查のためのベースが設けられた。採集物はそれぞれのベースに保管され，最終． 的には本部の Santiago に集結され，Varparaiso 港から日本へ発送された。

チリ側での主要調查地域は北から 1) Copiapo-Antofagasta 地域, 2) Santiago 地域, 3) Concepcion そその南方 Madre de Dios 地域であり，アルゼンチン側での主要調査地域は 1) Mendoza 地域，2) Patagonia 地域およびアンデスとの比較検討のための 3) Sierra Australes 地域とである。はじめにチり 側を北から南に調查移動し，ジープでチリ側からアンデスの峠を越えて，アルゼンチン側の Mendoza に 入り，北から南に移動調查した。チリ南部のフィヨルド地域にある Madre de Dios 地域を除けば，他の 調查地域はすべて気候条件にめぐまれた。北部チリの Antofagasta 地域では夏期に入る前であつたので, 砂漠の熱風がさけられたし，Patagonia では雨と烈風に逢うこともなく調査を終了した。気候条件をよく 調ベてベストシーズンに調查が実施できるようにすることがいかに海外遠征では必要であるかを知つた。

\section{IV. 現地での学術討論}

上記五主要地域のベースにおいて各地区ごとに現地の野外調査で知り得た内容などを中心に，既存の現 地側の知見と比較し，討論を行なつた。主な討論題目（A）と現地研究者（B）は次のようである。

1. Copiapo-Antofagasta 地域

(A) 層序・地質構造および Corals や Trigoniidae などの特徴 :

(B) Eduardo Abad E., Hugo Conn D., Aldo Moraga, Guillermo Chong D..

2. Santiago 地域

(A) 地質構造, 地史, チリ産 Trilobites, 中生代爬虫類：

(B) Carlos Ruiz F., José Corvalán D., Ernesto Egert, Federico Peebles, Renato Reys. B., Giovanni Cecioni.

3. Conccpcion ᄂ Madrc dc Dios 地域

(A) 古生界, 三畳系, 上部白巠系, 第三系, Fusulinids, Mesozoic plants, Trigoniidae など：

(B) Cesar Vergara E., Rodrigo Bustos S., Adela Aguilar, Lajos Biro B.

4. Mendoza 地域 
(A) 地質構造, 古生界, Trilobites, Palaeozoic Brachiopoda, Mesozoic plants など：

(B) Bruno A. J. BALdis, Ricardo H. CAstaÑeda V.

5. Patagonia 地域

(A) 地質構造, Mesozoic molluscas など :

(B) Armando F. Leanza, Otto Omar M., H. H. Chamacho, Héctor Leanza, Regina LEVY de C.

6. Sierra Australes 地域

(A) 古生界, Palaeozoic plants:

(B) 早瀬喜太郎, Sergio Archangelsky, Arturo J. Amos, Arturo Corte, Cesar Prozzi. なお，Santiago においてチリ国地質調査所員と討論会が開催された。われわれから，それぞれ，Madre de Dios 産 Fusuliniidae, Palaeozoic molluscas, 北部チリ産 Minetrigoniinae, Concepcion 地区からの Mesozoic plants, 上部白亜系・第三系閒の古地理の変遷についてなどの問題を提起した。これらの問題提 起や討論はわれわれが現地の地質・古生物に関する知識を整理する上で有意義であつた。

\section{V. 自然概観と研究成果}

1. Copiapo-Antofagasta 地域

1) Cerritos Bayos および Limon Verde

ここは Antofagasta の北東で, アンデスの脊稜山脈と Antofagasta とのほぼ中間位位置する。Cerritos Bayos 地区については BIESE (1956，1957，1961) の層位学的研究がある。すなわち, Sinemurian から Tithonian におよぶ約 3,500 m の海成層が欠除することなく連続しておるとし, さらに未記載の菊石, 腕 足類，斧足類，その他が多くの層準から産出するようになつている。したがつて，もし BIESE が認める ように地層が連続的に発達し豊富な化石帯が認められるならば，ジニラ紀の世界の化石帯の基準をこの地 で明確にすることも可能であると考えられ，今回の調査における最重要地域の一つとして精查計画をたて た。われわれの意図にもとづき，あらかじめチリ国地質調查所ではこの地域の予備調查を行なつた。その 結果は BIESE の報告に反し，化石の産出も少なく，化石帯も明確ではないということであつた。そこでわ れわれはチリ国地質調查所員と共にその点の確訫調査を行なつたが，その結果は予備調査のとおり BIESE のいう化石帯は不明であつた。Atacama 砂漠の北部に位置する本地域は, 標高およそ $2,000 \mathrm{~m}$ の高原で ある。この高原はアンデス山脈から由来した風化物が太平洋側に向かって運搬されて生じたもので，ゆる い平坦な地形をなす。そして，この高原上にはわずかに高い残丘があり，その残丘は安山岩などの火成岩 体，およびジュラ系から構成されている。ジュラ系は砂岩，頁岩，石灰岩を主とし，砂岩には偽層が発達 する。Limon Verde は Cerritos Bayos の南東に位置する高原上にそびえる山地（山頂：3,620 m) で, Domeyko range の北端の分岐した一部に相当する。本地区は砂岩, 頁岩, 石灰岩を主とするジュラ系で, 石灰岩中に化石が掃き寄せ状に産出する。化石は珪化している場合が多く, Frenguelliella sp., Weyla alata (von Buch), Mactromya n. sp., chlamys cf. textoria (SchlotheIM) などが知られる。 Frenguelliella sp. は新種であり, その他の Trigoniids には興味深いものが含まれる。Weyla は従来, Vola alata と呼ばれて lower〜middle Lias の示準化石として重視されている pectinid であるため, こ の産地の化石はこの時代のものであることはまちがいない。chlamys cf. textoria も lower〜middle Lias に沉世界的（ヨーロッパ，シベリア，日本，南米）に出る chlamys textoria によく似る。これら化石種 から Limon Verde の産地は，チリ側でも考えているように lower Jurassic であることは疑いない。

\section{2) Domeyko range}

Domeyko range の地質調查はあまりすすんでいないし，特に古生物学的研究は非常におくれている。 Domeyko range は Antofagasta の東方にあって, アンデスの主峰山脈の西に南北走るいわば前山の山 


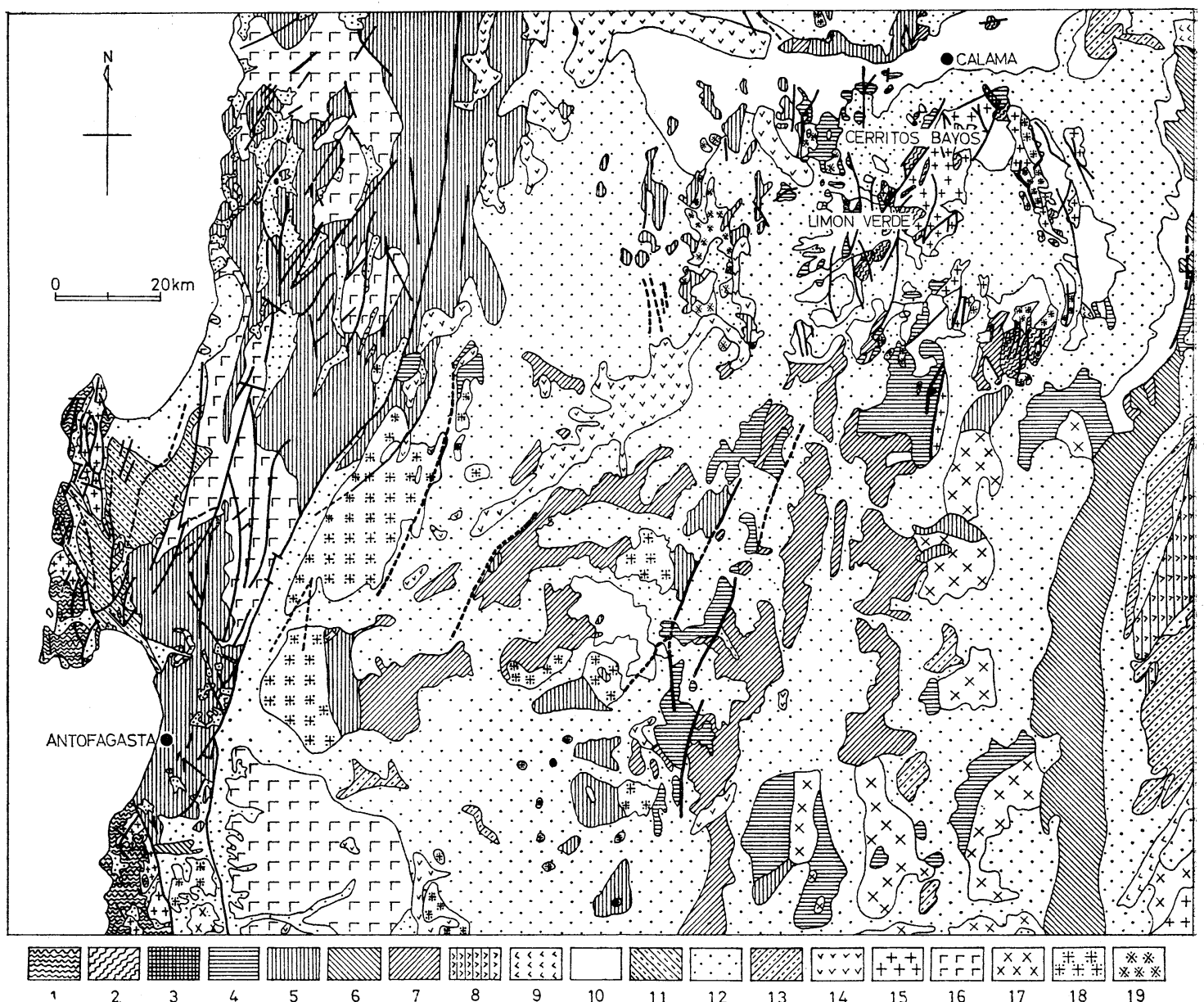

第 1 図 チリ北部 Calama 地方の地質図（チリ国地質調查所，1968による）

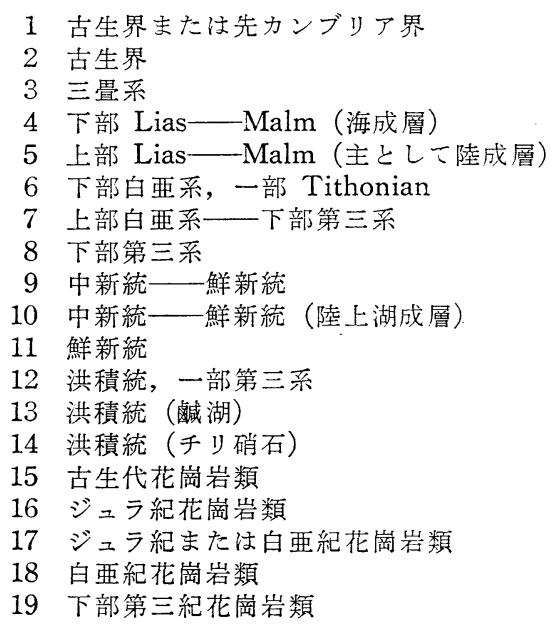


脈で，高さは約 3,500 4,500 $\mathrm{m}$ におよぶ。われわれは Domeyko range に分布する中生界の数地点を調 查したが，はげしい作業を除けば，高地で㲘念される身体上の障害は生じなかつた。

Domeyko range の西斜面の調查地では砂岩, 頁岩の互層からなり, 地層はかなり褶曲し, 変形は著し い。しかし，頁岩中の nodule からかなり保存のよい化石が発見され，一部に石灰質の款の残つているも のが認められる。採集した化石から次のような種属が判明した。Cardinia sp., Protocardia n. sp., Astarte sp., Thracia sp. など。これら種属のうち, Astarte の幼年期のものが細粒砂岩ないし砂質頁岩 中に層状の産状をもつて多産し, Astarte bed をつくる。これら産地の地質時代は化石種から lower Jurassic であることは疑いない。

いつぽう, Domeyko range の東斜面の調查地の岩相は西斜面のものとかなり相違し, 砂岩, 頁岩およ び石灰岩からなる。化石は珪化がすすみ，石灰岩中に多く含まれる。Eopecten sp., Pinna sp., Modiolus sp., Minetrigoniinae gen. and sp. nov. その他の二枚貝類, 腕足類, corals などが知られる。この地の Minetrigoniinae のものは，表面に同心円状の肋と放射状肋とがまじわり，日本産 Minetrigonia によく 似るが, carina が Minetrigoniinae 中では非常に広く, 新属である。

\section{3) Copiapo}

Copiapo 地区は銅，鉄などの鉱山が多いため地質図がもつともよく作成されているが，古生物学的研究 はあまりすすんでいない。この地区にはジュラ紀と白亜紀の海成層があるが，ジュラ系に化石が多い。ジ 二ラ系は粗粒砂岩, 厚い暗灰色石灰岩および部分的に磁岩からなる。粗粒砂岩中には二枚貝類が多く, 石 灰岩中に珪化した Trigonia sp. および Trigoniidae の新属, 新種が含まれることを新たに知つた。

\section{Concepción 地域}

チリの首都 Santiago から太平洋岸にそつて約 $600 \mathrm{~km}$ 南下した地点に Concepción があり,ここはこ の地域の中心都市で,われわれはこの地域の中生界, 新生界について野外調查を行なつた。すなわち, Bio Bio 川の下流流域に古くから知られている三畳系, および Bio Bio 川河口の Talcahuano とその北 に位置する海軍基地 Quiriquina 島に分布する上部白亜系および第三系を調查して, 多量の動植物化石お よびその他の堆積物を採集した。特に Quiriquina 島の上部白亜系上部層準から新たに 豊富な化石植物群 を発見した。また一方, 上部白亜系および始新世のそれぞれの基底磁岩層を堆積学的立場から調查し, 古 地理の考察を行なつた。

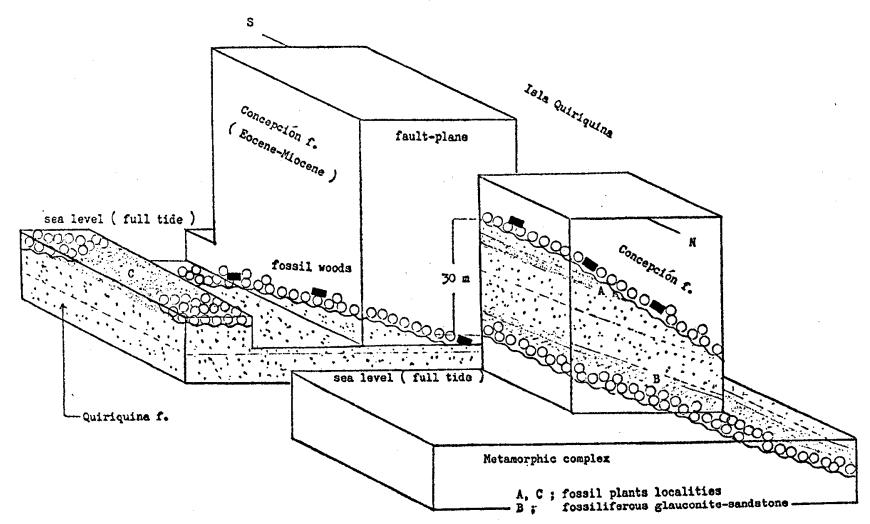

第2図 Quiriquina 島の地質構造

\section{1）Bio Bio 川下流流域の三畳系}

JEREZ（1960）によれば，この地域の三畳系はかなり複雑な構造を示し，粘板岩・硬砂岩・アルニース 
砂岩, 礫岩からなり, Bio Bio 川の東側ではつぎのような層序になる。

一Talcamávida-Gomero 層（上部湖沼成層）…層厚 3,000-3,500 $\mathrm{m}$ に達していたものと推定 され，Unio，Estheria および植物化石を産する。

-Uniue 層（中部海成層）…Halobia neumayri にとみ，まれに植物化石を産し，層厚 2,500一 $3,000 \mathrm{~m}$ と推定される。

一 Quilacoya 層（下部陸成層）…炭層を注さみ, 全体が陸成の堆積物からなり, Unio のほか植物 化石を産する。層厚 $1,500 \mathrm{~m}$ 。

以上の東側地域の三畳系の上下両限の層序関係は不明であるが, 北側では, 結晶片岩類と断層関係で接 するようであることを確認した。

Bio Bio 川の西側では，層序は上記東側と著しく異なる。JEREZ によれば, 層さ $3,000 \mathrm{~m}$ と推定される 礫岩層およびその間にはさまれる細粒海成砂岩の薄層とからなり, 後者中に Phaenodesmia cfr. peruana JAWORSKI を含み, 東側の三畳系については, 上部層は Rhaetic にまで達し, 中部層は Carnic, 下部層 は Carnic 下部を代表するものとみなしている。そして下部層の下位から, Linguifolium lillieanum ARBER, L.? steinmanni SOLMS-LAUBACH? その他を, また上位からは, Pterophyllum sp., Baiera sp. cfr. paucipartita NATHORST などを報告し, 中部層からは, Phaenodesmia sp., Halobia neumayri BITTNER などを, さらに上部層からは, Thinnfeldia (Dicroidium) lancifolia (MORRIS) GOTHAN な どをそれぞれ報告した。

しかしながら,この地域の植物化石についての古植物学的研究は未だなされていない。したがつて，わ れわれはおもに Bio Bio 川の西側地域において植物化石の採集に努め, 断片で保存状態はよくなかつた が相当量の標本を入手，さらに東側地域において採集を行ない，とくにUnihue 部落の南方約 $2 \mathrm{~km}$ の地 点において中部層相当層のやや風化した粘板岩中に, Halobia その他の動物化石をともなう多量の植物化 石を発見し採集した。この植物化石は印象ではあるが，古植物学的に興味あるものが多い。また Halobia は小林貞一博士により検討がなされつつある。なお，アルゼンチンの San Juan 地区の調查の途次 Barreal そおいて，三畳紀の植物化石の採集を行ない，それらも目下検討中である。

\section{2) Quiriquina 島およびその周辺の上部白亜系および始新統}

Talcahuano, Tumbés 半島および Quiriquina 島には, 結晶片岩・千枚岩などの変成岩からなる古生界 を不整合におおい，アンモナイトをはじめとする頭足類, 斧足類, 腹足類, corals, 魚類などの化石を豊富 汇含む上部白亜系 Quiriquina 層（Senonian）が分布し，さらにこの上部白带系を不整合の関係で始新 統がひふくしている。Talcahuano おょび Quiriquina 島において Quiriquina 層の動物化石，とくに Trigonia の採集を行なうと共に，同層の層序について検討中，同島の北端斜面において 同層上位と考え られる細粒砂岩中より双子葉植物化石を発見した。さらに従来は始新統のみ分布するとされていた同島の 東海岸の海食台において, 顕著な始新統の基底碟岩におおわれる Quiriquina 層の分布を新たに確認し, そこから豊富な上部白亜系の化石植物群を発見した。WERNER（1964）は Quiriquina 層に植物化石を産 すると述べているが，これは下位の動物化石とともなつて産する断片を指したもので，ここでいう上位の 新化石植物群のものではないことが明らかとなつた。Quiriquina 島での Quiriquina 層の層序は第 1 表の とおりである。

Quiriquina 植物群の構成は双子葉植物を中心にかなり豊富であり,さらに花粉・胞子化石を含んでいる。 南アメリカでの花粉学的研究は緒についたばかりであり, 白亜紀花粉・胞子については ARCHANGELSKY \& GAMERRO (1965, 1966), HERBST (1970), MENÉNDEZ (1965), BRENNER (1968) などの研究があ り, 今後その進展が期待される。木村の予察的観察によると北半球のとくに太平洋沿岸地域に共通に産出 する特異な花粉型 Aquilapollenites 状のものは未だ本地域からは見出されておらず，あるいはこのことか ら ZAKLINSKAJA のいら花粉植物地理区の設定の考えに資料を提供できるかもしれない。この植物群の全 


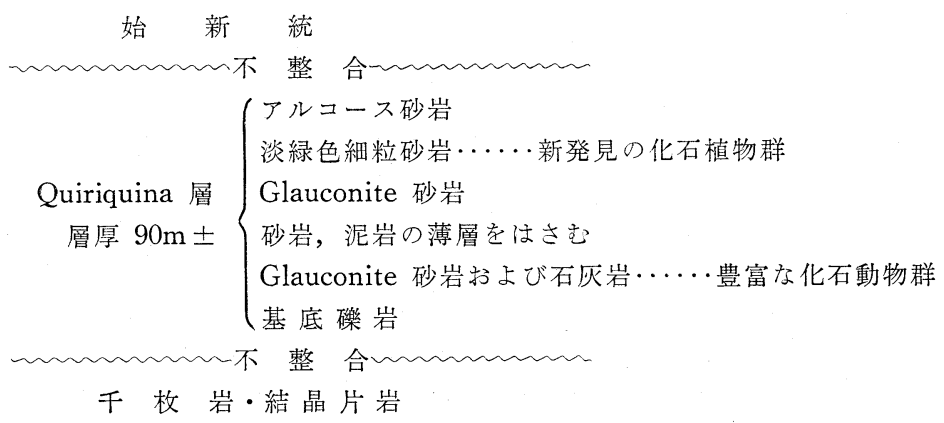

容が明らかにされたときは，おそらく南半球の Senonian-Maestrichtian 植物群の代表的なものとなる可 能性が大きく，将来の調查の継続がのぞまれる。

Quiriquina 層を顕著な不整合でおおう始新統とされている地層は, Concepción の南 Coronel で稼行 中の海底炭層をはさむ始新統とされているものとほぼ同層準のものであると考えられ, 同統の基底部に豊 富に産する珪化木の多数を採集した。

\section{3）上部白亜紀～第三紀の古環境}

この地域に関する堆積学的立場からの古地理の考察は，これまでのところ全く知られていない。Quiriquina 島に分布する上部白亜系および第三系の基底礫岩層を調査し, 両者の特徵から古環境の考察を試み

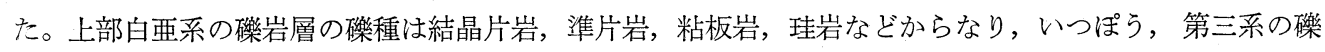
種は各種の斑状火山岩類, 酸性深成岩類, 凝灰岩, 碟岩, 片麻岩および結晶片岩などからなる。このう ち，塩基性ないし中性火山岩類が圧倒的に多く，それらは $60 \%$ 前後を占める。粒度組成は両者とも粒径 32 64 mm の pebble を50\%以上含む。しかし，上部白亜系の礫は相対的に粒径が大である。扁平度に ついては上部白亜系の礫は第三系の䃯に比し，全般に扁平度が大きい。円形度については，上部白亜系の 碟は角礫から円碟まで各段階のものを含むが，亜角碟が卓越し，水の営力を長く受けた形跡が少ない。こ れに対して第三系の礫は相対的に円形度が大であり，特に粒径 $32 \sim 64 \mathrm{~mm}$ のものはきわめてよく円磨さ れている。

以上のような諸事実から，両者の礫岩相の差異は，上部白亜系の堆積以降，第三系の堆積する期閒中 に, 堆積盈地や後背山地に大きな変動のあつたことを示すもの 上考えるに至つた。

\section{Madre de Dios 地域}

南緯 $49^{\circ}$ から以南の Ultima Esperanza, Magallanes および Tierra del Fuego の諸州は南米大陸が南極大陸に向つてL字 状に屈曲する部分にあたり, 海岸山脈とアンデス山地はもつと も低くなるところである。当地方は全般的に氷河の浸食をう け, 内陸部にはU字形の水食谷がいたるところに発達し, 海岸 には Fiord が発達する。

当地方の気温は Punta Arenas で年平均気温が $6.5^{\circ} \mathrm{C}$, 降水 量は偏西風のため非常に多く，西方の島では年間降水量が 3,000 mm をこえる。調査した Madre de Dios 諸島は，この 地方でもとくに気候条件の悪い地域で，たえず強風が吹き，晴 天は10日間に半日（しかも午前中）ぐらいのようである。

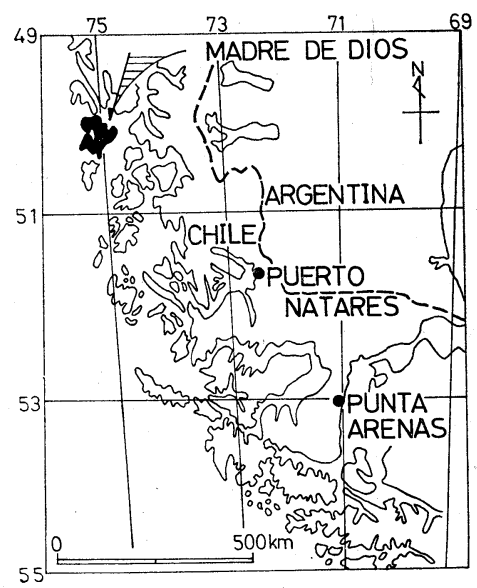

第 3 図 Madre de Diosの位置図 (南緯, 西経) 
Puerto Natales から Madre de Dios まで船で片道 3 日 3 晚を要した。

Madre de Dios 諸島の Guarello 島から Schwagerina, Triticites が産出することは既にCarlos RuIZ F。・外（1965）によつて報告されている。本島はおもに石灰岩層からなり，部分的にチャート，頁岩をは さむ。地層の変形が著しく構造は複雑で, 詳細は将来の精査にまたねばならないが, 調查した限りで汶本 島の走向・傾斜はおよそ $\mathrm{N} 40^{\circ} \mathrm{E}, 50^{\circ} \mathrm{E}$ で，本島の東側ほど上位の層準と推定される。本島附近の詳細な

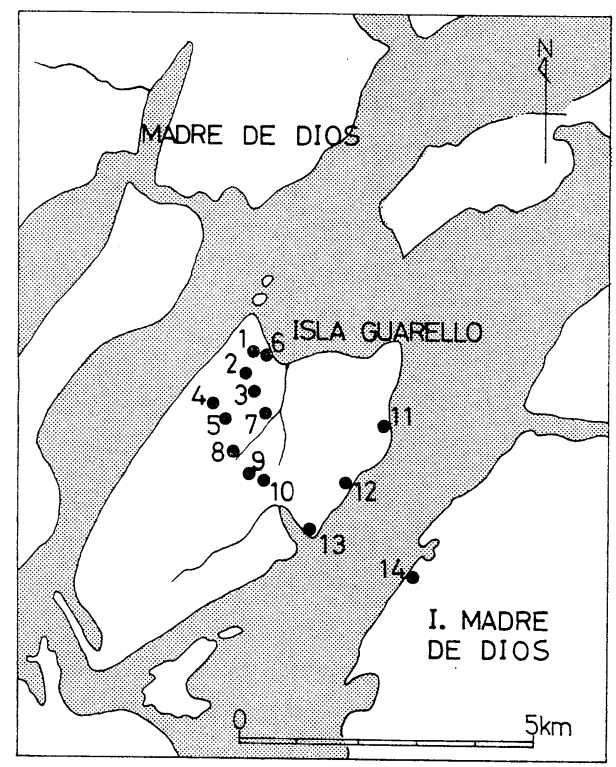

第 4 図 Isla Guarello の化石採集地点図 地質図はまだできていない。われわれは下記の 14 地点から資料を採集した。以下各地点 (No. 1 14) の特徴安記す。(第 4 図参照)

No. 1 ; 灰白色塊状の石灰岩で紡錘虫は発見され なかつた。No. 2; 種々の岩石片を含む不純な石圧 岩で, Triticites sp. A を産する。本種は紡鍾形を 呈するが非常に小型で, spirotheca と septa は非 常にうすく, septa の褶曲は軸付近のみにみられ, chomata は明膫である。本邦ではこれに類似する ものはみあたらない。No. 3; 灰白色塊状の石灰岩 で，化石の個体数法非常に多い。Triticites sp. A, Triticites sp. B などを産する。後者は，殼は円筒 状で septa は非常に細く, septa の褶曲は著しく 強く, それらは中央部までおよぶ点からみて, Triticites ellipsoidalis に類似している。しかし Triticites sp. B は Triticites ellipsoidalisより も殼は細長く, septa の褶曲が強い。その他， $P$ seudofusulina sp. を産する。No. 4 ; 岩相は No. 3 と似ている。化石の個体数は少なく, Triticites sp. A, Triticites sp. B を産する。No. 5 ; 灰白色, 塊状の石灰岩で化石が非常に多く入つている。 Triticites sp. A, Triticites sp. B を産する。No. 6 ; 不純な石灰岩で, Triticites sp. A, Triticites sp. B を産する。No. 7 ; 不純な石灰岩で, Pseudofusulina sp. を産する。No. 9 ; 灰白色, 塊状の石灰岩で 化石は現在のところまだ，みつけられていない。No. 10 ; 暗灰色の石灰岩で化石はまだ発見されていな い。

No. 1 から No. 10 までは Schwagerininae の化石であるが, 推定される地質構造からみて, 島の東 岸，すなわち見かけの上部層準では Neoschwagerininae などの化石が採集可能ではないかと考え，調查 地を拡げた。No. 11 ; 珪質の石灰岩では化石は発見されなかつた。No. 12 ; 灰白色の石灰岩で，紡錘虫は 含まれていない。No. 13 ; 岩質は No. 12 のものと似ているが紡錘虫は発見されなかつた。

Guarello 島の東岸で Neoschwagerininae を発見することができなかつたので，さらに東方にあたる島 （No. 14）を追跡調査したが，砂岩，頁岩の互層で含化石相は見出されなかつた。

現在までの室内研究により判明したことは次のとおりである。わが国の Neoschwagerina zone や Yabeina zone では属や種の種類が多いが, いつぽう本調査地では同一種の個体数はきわめて多いが種類 は少ない。

本邦の Triticites についての高岡善成 (1959) の興味梁い研究によれば T. matsumotoi 型, $T$. exsculptus 型および T. ellipsoidalis 型に分けられているが, Guarello 島産の Triticites sp. B は, 外 形は elongate し, septa の褶曲が強く, 中央の部分にまでおよんでいる。以上の点よりみて Triticites sp. B は Triticites ellipsoidalis 型に属しているものとおもわれる。なお鳥山隆三 (1959) の詳細な研究 
によれば, Triticites ellipsoidalis は秋吉では Pseudofusulina vulgaris subzone P $1 \beta$ (下部二畳系) か ら報告されている。石炭系上部を指示する Triticites matsumoto $i$ 型や石炭系中部および二畳系の Parafusulina zone, Neoschwagerina zone, Yabeina zone の化石はいまだ本調查地より発見されていない。

\section{Mendoza 地域}

アンデスの分水嶺から東のアルゼンチン側では，南部においてはそれほど著しくはないが北半には幾条 かの Sub-Cordillera あるいは Pre-Cordillera が発達し, さらに北方のボリビアやペルー内ではこれらが 互いに癒合して平均高度が $4,000 \mathrm{~m}$ をこす高原となる。

このような諸山脈の分岐あるいは雁行は, 地質学的に非常に重要な意味をもつ。一般に Mendoza 州か ら北の部分では, こういつた山脈は大きな衝上断層を伴うことが多く, その部分に, より古期の諸岩層が 露出する (第5 図参照)。チリ側で確認されている唯一のオルドビス紀化石産地である Salar de Atacama 周辺も, 類似の地質構造をもつ。アルゼンチン側では, Mendoza, San Juan, La Rioja, Catamarca, Salta, Jujuy の各州に, カンブリア—オルドビス紀の下部古生層をはじめ, シルル——゙ボン系などが各所に 露出する。今回の調查では, Dr. BALDIS が目下調查をすすめて，構造が詳細である San Juan 地区をえらんだ。調查ルートは Mendoza から Uspallata, Calingarta, San Juan, Talacasto, Jáchal などを経由して La Rioja との州境に近い Blanco 川流域 に至り, およそ $1,000 \mathrm{~km}$ を経て, ふたた び Mendoza へもどつた(第 5 図)。ここで の調查の主要目標は代表的地域での層序の 確認と, 古生物学的資料の収集とである。

\section{1) La cuesta de Villavicencia}

Mendoza から Uspallata 越える峠は, 厚いフリッジュ型の中部デボン系からな り,ところどころに生痕がみられるのみで, いわゆる有款化石の類は発見されていな い。その上位の Yabeiella などの植物や魚 化石，Estheria などを含む 陸成三畳系を 確認した。

\section{2) Calingasta}

Calingasta 南方の Barreal に近い Quebrada Cortaderita 海露出する三畳系は雑 色の砂岩・頁岩からなり, 多量の植物化 石を産出する。おもな化石としては, Zuberia, Dicroidium, Saportaea (Barrealia として記載された）ものなどがあ る。

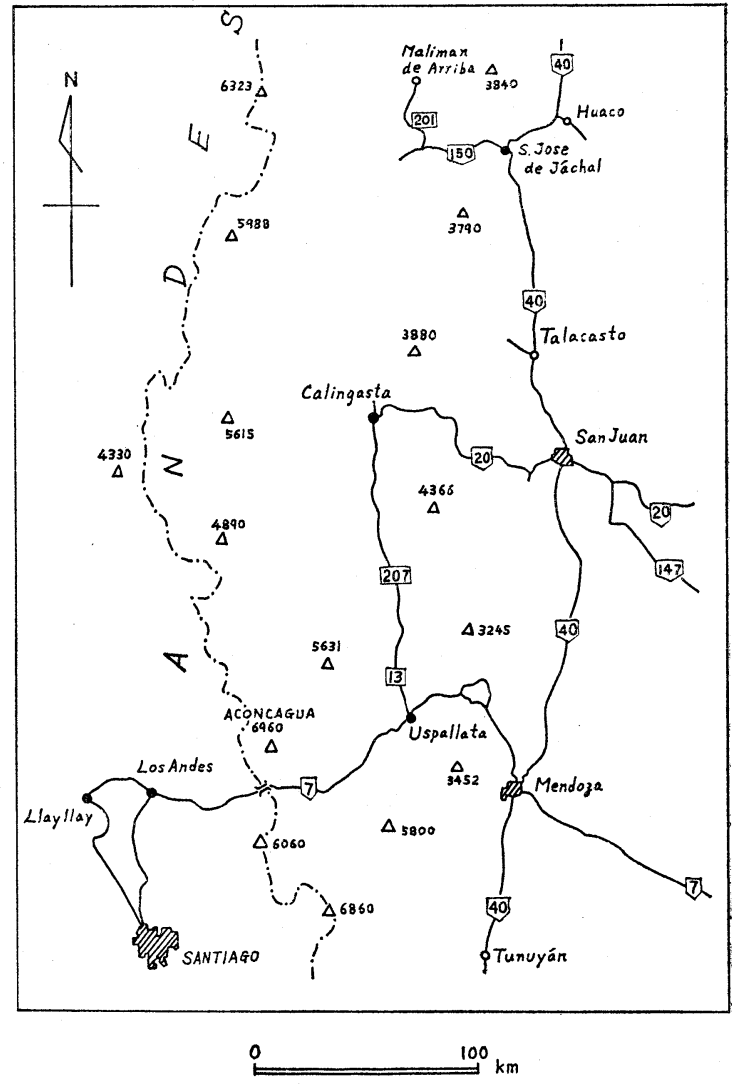

第 5 図 Mendoza 地域のルートマップ

Calingasta の北の La Capilla には，断層に沿つて中部石炭系の小レンズ状体が分布しており，その一 部にコキナ状の腕足類化石帯が含まれる。Kitakamithyris septata (CHRONIC), “Neospirifer”leoncitensis (HARRINGTON) などのほか, Fenestella や Polypora などの蕉虫類も多産する。

3) Calingasta-San Juan 


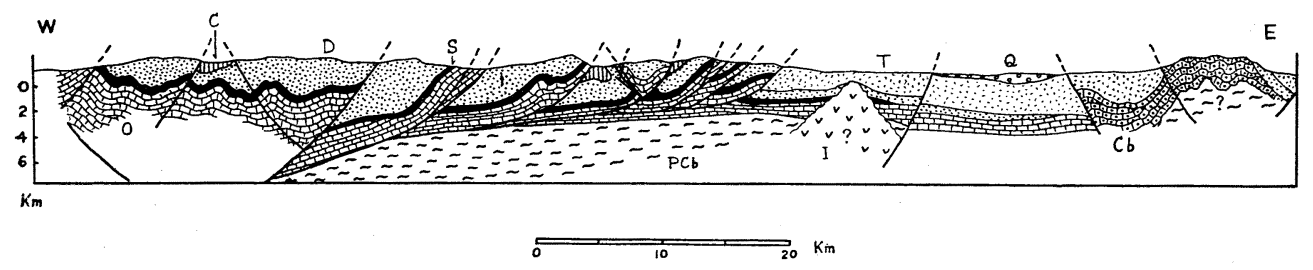

第6 図 Calingasta-San Juan の地質断面 (BALDIS \& CHEBLI, 1969 による)

第 6 図の断面図に示されるように，ほぼ東西にきざみこまれた San Juan 川の深い谷沿いは，PreCordillera の地質構造がよく発達し, 巻貝などを含むオルドビス紀の石灰岩が露出する。シルル紀は化石 に乏しく，かつ層厚も小さいが，それに続く下部デボン系は主として砂岩・頁岩の互層からなり，三葉 虫, 腕足類, 頭足類, 海百合, 床板サンゴ, “Chondrites”などを含む。Tambolar におけるこの層準か ら産出する腕足類には，Australospirifer やAustralocoelia などマルビノカフリック動物区の特徴属 が含まれ，また床板サンゴとしては，非常に長い樹枝状の群体をもつ“Favosites”を産する。この “Favosites” はかつて F. argentina THOMAS として記載され，シルル紀のものと考えられたが, 1959 年に浜田はこれがデボン紀的要素をもつものであることを指摘し，その地質時代については再検討の必要 を予想していた。今回の調査によつてこの“Favosites”がデボン紀前期のものであることを確認するこ とができ，さらに同行の Dr. BALDIS もまた層序学的な立場から同様の結論を得ていることが明らかとな つた。なおこれらの化石とともに，魚類の骨片が得られたが，これはアルゼンチンにおけるデボン紀魚類 の最初の発見である。

\section{4) Talacasto 地区}

Talacasto から西に入る谷の大口には, オルドビス紀 (ランビルン世) の石灰岩が露出し, orthids を 主とする腕足類一三葉虫化石群を含んでいる。その西方には砂岩・頁岩からなるシルル系〜中部デボン 系が広く分布し，化石は比較的にまれではあるが，場所によつては Atrypina のコキナ層（上部シルル采 や，大型三葉虫の “Homalonotus” を含む塊状砂岩（下部デボン系）などが見出され，後者は腕足類 “Schelwienella”を伴なう。当産地においても，転石ではあつたがシルル〜デボン紀のものとおもわれ る魚類の骨片が得られたことは特筆に值いしよう。

\section{5) S. Jose de Jáchal 地区}

町の南西にあるセメント工場裏には，シルル紀中期の化石を含む，小さいが著名な露頭がある。Atrypina-Phacops 帯に属し, 砂岩・泥岩の互層からなる低い丘の表面には, 多数の化石が散乱している。 "Phacops" sp., Atrypina acutiplicata KAYSER の他に, “Chonetes”, Australina, "Tentaculites" などが認められる。Australina は A. jachalensis CLARKE で，ここを模式地とするものである。

6) Maliman de Arriba 地区

アンデス深くに源を発して南下する Blanco 川の左岸にかかつている Chavela 谷の上流には, 中〜下 部デボン系がよく発達し, 豊富な三葉虫群を蔵している。三葉虫は Dr. BALDIS によつて研究されつつあ るが, Metacryphaens argentina BALDIS がもつとも多数を占め, 頁岩中の卵形の nodule 中に発見され た。その他まれに Acanthopyge ballivianii (KOZLOWSKI) や Cryphaeoides rostratus (KOZLOWSKI) が見出される。また植物化石 Haplostigma furquei FRENG をも産出する。なお，この地域においても， またまたデボン紀魚類の骨片がいくつか得られたことは，きわめて興味深い。

7) San Juan 地区

San Juan の西部にあたるZonda 地区のカンブリア紀石灰岩は，ほぼ垂直に近い角度をなすまでに変 位しているが，いくつかの化石帯が認められ，三葉虫を多産する。

上述の要約に明らかなように, 今回の調査の中心はシルル・デボン紀におかれていたのであるが，とくに 
"Farosites", argentina の産出層 準が明らかになつたことと，破片で はあるがデボン紀魚類化石を，アル ゼンチンとしては最初にしかも各所 から発見し得たことなど，本調査地 域での大成果であつた。とくに後者 に関しては, 将来の精査によりシル ルデボン系の分帯を魚化石によつて 行なう可能性をもたせるに至つたも のであり, 国際対比上の意義は大き w。

\section{Sierra Australes 地域}

この地域の中心に Bahia Blanca がある。Bahia Blanca の北方に は，広大なパンパにきわ立つてそび える南部山脈 (Sierras Australes) が，北東に張り出した弧をえがいて 連なり，その南東端が平原に没する 近くに“空の山” (Sierra de la Ventana）と呼ばれる山塊がある。 この山塊は主として先カンブリア代 の地層と，その上に不整合で重なる シルル・デボン系および二畳系とか らなつている。これらの中・上部古 生層からは, いわゆる南半球型の特 徵をそなえる各種化石群が発見され ており，1967年に開かれた「ゴンド ワナの層序学・古生物学に関する第 一回国際シンポジウム」(1 International Symposium on Gondwana Stratigraphy and Palaeontology) に際し, 野外巡検地の一つに選定さ

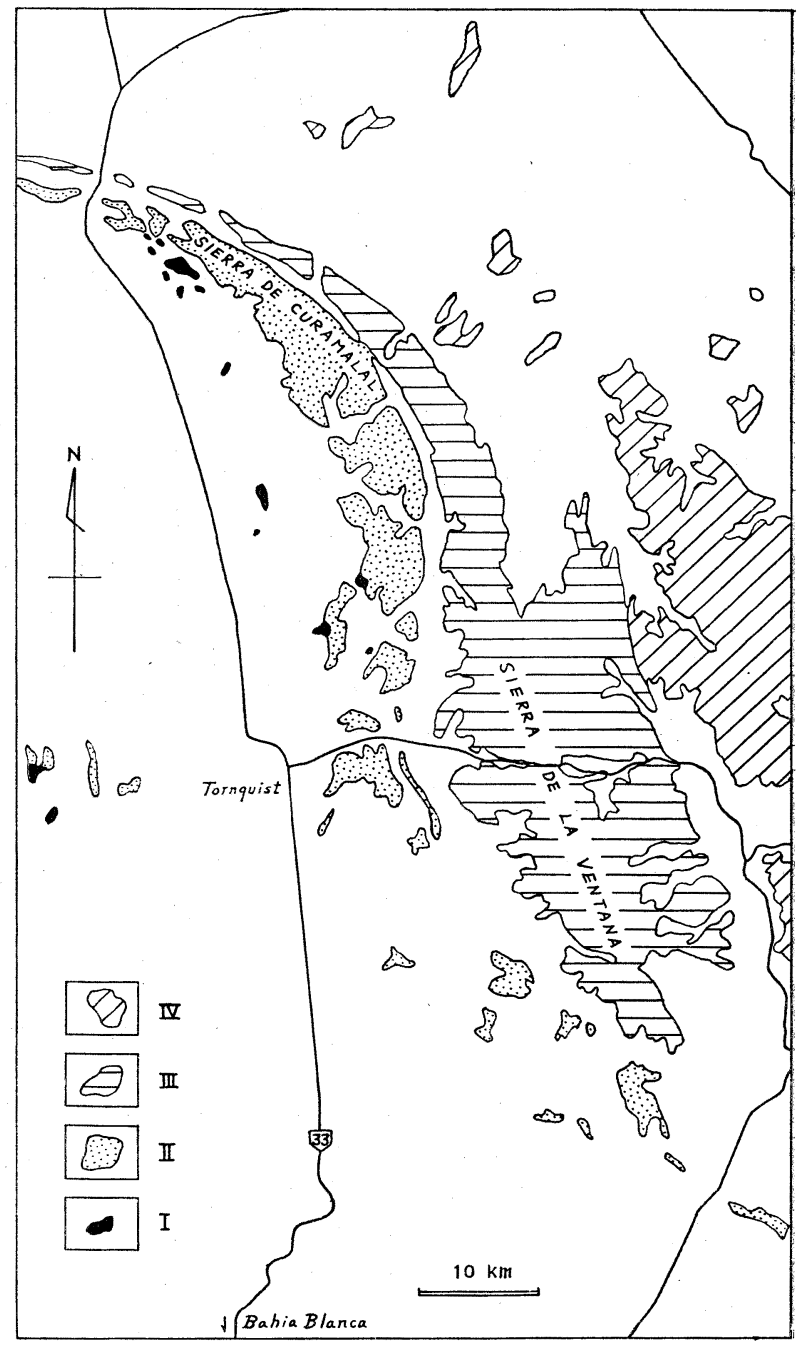

第 7 図 Sierra de la Ventana 周辺の地質 (HARRINGTON in PADUla et al., 1968 による) れている。

当地区の調査目標は, マルビノカフリック要素として重要なシルル・デボン紀の腕足類, とくにCryptonella を得ること，ならびにゴンドワナ特有の二畳紀植物 Glossopteris などを入手することにあつた。 短期間の調査ではあつたが, Universidad Nacional del Sur の地質学鉱物学教室の Dr. HAYASE, Dr. PROZZI, Dr. CORTE をはじめ, 多くの方々の協力を得て無䭾なく調査をすすめることができた。

Sierra de la Ventana に分布する古生層の層序は次のとおりである。

IV Pallahuinco $\begin{array}{cr}(\text { 二瞢系 }) \\ 2,200 \mathrm{~m}\end{array}$ 層群 $\left\{\begin{array}{lr}\text { Tunas 層 } & 600 \mathrm{~m} \\ \text { Bonete 層 } & 400 \mathrm{~m} \\ \text { Piedra Azul 層 } & 300 \mathrm{~m} \\ \text { Sauce Grande 層 } & 800 \sim 900 \mathrm{~m}\end{array}\right.$




\begin{tabular}{|c|c|c|c|}
\hline \multirow{3}{*}{ III } & \multirow{3}{*}{$\begin{array}{c}\text { Ventana 層群 } \\
\text { (下部デボン系) } \\
\text { 1,400m }\end{array}$} & Lolén 層 & $400 \mathrm{~m}$ \\
\hline & & Providencia 層 & $200 \sim 300 \mathrm{~m}$ \\
\hline & & Napostá 層 & $400 \mathrm{~m}$ \\
\hline \multirow{5}{*}{ II } & & Bravard 層 & $200 \sim 250 \mathrm{~m}$ \\
\hline & & ( Hinojo 層 & $100 \sim 150 \mathrm{~m}$ \\
\hline & Curamalal 層群 & Trocadeo 層 & $700 \sim 800 \mathrm{~m}$ \\
\hline & $1,250 \mathrm{~m}$ & Mascota 層 & $200 \mathrm{~m}$ \\
\hline & & La Lola 層 & $100 \mathrm{~m}$ \\
\hline
\end{tabular}

各層群はいずれも不整合によってへだてられているが，I－II間は斜交不整合であり，II－而間は非整 合，III一IV間は不整合の関係にある。II 層群は主として quartzite からなり，基底部に法粗粒砂岩や䂰岩 なども含む。III層群も粗粒砂岩および碎岩にはじまり，雑色の砂岩が主体であるが，全体として片理がよ く発達している。Cryptonella などの腕足類はこのような変形した砂岩中に含まれ，とくに Lolén-Providencia 層の境界から約 $80 \mathrm{~m}$ 上位の層準に多く見出される。いずれも殸は溶脱しているが, 次の 5 種を 産出する。Cryptonella baini SHARPE, Schuchertella sp., Spirifer indet., “Leptocoelia flabellites" (CONRAD), Derbya sp.. 目的とする Cryptonella は, かなり再結晶の進んだセりサイト片岩〜千枚岩中 に，一見砂岩状に密集して産出する。したがって保存状態は著しく貧弱であるが，変成岩中の大型化石之 してその産状はきわめて示唆にとんでいる。

IV 層群はやはり碟岩を有するが，全体として細粒物質が優勢となり，細粒砂岩やシルト岩が多い。III層 群とは変成度に著しい差があつてほとんど “生”に近く，変形玉少ない。いろいろな層準にある磉岩中 には，研磨されたり擦痕を有する礫を含むので，多分， tillite であろう。Bonete 層は化石を多く含み，主 として砂質岩中に, 数種の Eurydesma をはじめとする特徵的な二枚貝化石群を産出する。これらの海椿 動物群を含む地層の上位には Modiola を伴う含植物化石層が発達し，塊状のシルト質岩中に下記のよう な各種を産する。Glossopteris angustifolia BRONGNIART, G. browniana BRONGNIART, G. decipiens Feistmantel, G. indica SHIMPER, Gangamopteris obovata (CARR.) ARGER, G. obovata var. major Feistmantel, Noeggerathiopsis hislopi (Bumb.) Feistmantel, Walkiella sp. indet., Equisetoid stems (Neocalamites?)。

気候上の厳しい悪条件下ではあつたが, Tornquist 東方の趾近くでの Cryptonella, および Las Mosazas の石切場での Glossopteris やその他多数を採集することができ，それらは目下検討中である。

本研究に当つて種々とご教示たまわれた千葉大学長相磯和嘉博士に対して, また東京大学名誉教授小林 貞一博士，東京教育大学名誉教授藤本治義博士，三菱鉱業朱雀智介氏，堀越義一氏，海外釷物資源開発小 川泰司氏掞よび入辻昭氏，Buenos Aires の島津重一氏，General Alvear の小林敬吉氏および日本貿易振 興会に対して梁く感謝する。なお本研究は文部省科学研究費助成による海外学術調查であつて, 当局関係 者からの多方面にわたる深いご配慮に対して，ここに嬮く謝意を表する次第である。 